International Research Journal of Management, IT \& Social Sciences
Available online at https://sloap.org/journals/index.php/irjmis/
Vol. 8 No. 3, May 2021, pages: 296-305
ISSN: 2395-7492
https://doi.org/10.21744/irjmis.v8n3.1696

\title{
The Structure of Company Ownership and Tax Avoidance in Indonesia
}

\author{
Wima Rakayana ${ }^{a}$ \\ Made Sudarma $^{b}$ \\ Rosidi $^{c}$
}

\section{Article history:}

Submitted: 27 March 2021

Revised: 18 April 2021

Accepted: 9 May 2021

\section{Keywords:}

annual report; company ownership; company policy; ownership structure; tax avoidance;

\begin{abstract}
This study aims to explain the effect of ownership structure (family, government, institutional, foreign, managerial, public) on tax avoidance in Indonesia. This study employed quantitative research with regression analysis, regression method using the annual report on companies listed on the Indonesian stock exchange from the 2017-2019 period with a sample of 93 companies. The tax avoidance was measured using the Cash Effective Tax Rate. The results of this study indicate that the government ownership structure and foreign ownership structure have a positive effect on tax avoidance in Indonesia. Firm size emphasizes the influence of the independent variables on the dependent variable. Family, institutional, managerial, public ownership structures have no influence on tax avoidance. This study indicates that the ownership structure of the company can influence company policy in tax avoidance.
\end{abstract}

International research journal of management, IT and social sciences (C) 2021. This is an open access article under the CC BY-NC-ND license (https://creativecommons.org/licenses/by-nc-nd/4.0/).

\section{Corresponding author:}

Rakayana, W.

Faculty of Economy and Business, University of Brawijaya, Indonesia

Email address: wimarakayana777@gmail.com

\footnotetext{
${ }^{a}$ Faculty of Economy and Business, University of Brawijaya, Indonesia

${ }^{b}$ Faculty of Economy and Business, University of Brawijaya, Indonesia Faculty of Economy and Business, University of Brawijaya, Indonesia 


\section{Introduction}

Taxes are compulsory contributions that are paid to the state by being forced on individuals and entities that are regulated by law. Based on Law Number 16 of 2009 concerning general provisions and procedures for taxation. The tax sector is one of the main revenue sectors for the Indonesian state. This can be seen from the state budget that has been budgeted by the government, where tax sector revenue contributes $75 \%$ of the state budget. However, the realization of the tax revenue target from 2017-2019 is only around 84\% - 92\%. This illustrates that the tax collection has not been maximized from taxpayers (Ministry of Finance, 2019). Not achieving the tax target set by the government indicates the non-compliance of the Indonesian people in paying their obligations to the state.

Based on data from the Ministry of Finance of the Republic of Indonesia, it is noted that Indonesia's tax ratio is still lagging behind other countries in the ASEAN region, which have a tax ratio of around 15-17\%. Indonesia's tax ratio in 2017 was $10.9 \%$, in 2018 it was $11.6 \%$ and in 2019 it was $12.6 \%$. The low tax ratio in Indonesia indicates that taxpayer compliance is still low. Furthermore, Indonesia's tax ratio is still lagging behind other countries in the Southeast Asia region. Meanwhile, in 2017, Singapore reached a $14.10 \%$ tax ratio, Malaysia reached $13.76 \%$, and Thailand's tax ratio reached $17.69 \%$.

The low tax ratio in Indonesia is due to low mandatory compliance, which indicates that there are still many taxpayers who do tax evasion and tax evasion in Indonesia. The number of tax avoidance actions is because the tax burden for taxpayers is an expense item that must be paid in accordance with applicable regulations (Amri, 2017). The tax burden for companies that are imposed on taxable profits can reduce the net profit generated by the company (Suandy, 2011). This encourages companies to try to pay as little as possible or avoid taxes.

Tax avoidance behavior can be influenced by agency problems in agency theory (M. C. Jensen \& Meckling, 1976). Information held by management is used to increase management compensation with high profits. On the other hand, shareholders expect an increase in share value by complying with the existing tax regulations. In order to harmonize the principal's desires, agency cost is required. This aims to encourage agents or management to protect the interests of shareholders in order to achieve the desired goals.

According to agency theory, the ownership structure is a governance mechanism to reduce the interest between the principal and agent (M. C. Jensen \& Meckling, 1976). The ownership structure mechanism is one of the factors to reduce the imbalance of information used by management for opportunistic actions and willingness to run the company according to the wishes of shareholders. The ownership structure of an entity can affect the company's nets on the company's performance and decision-making. A concentrated ownership structure can be a cause for tax avoidance. Tax avoidance practices make it a strategic choice for management to increase profitability by reducing the company's tax burden.

Previous studies related to ownership structure and tax avoidance have shown inconsistent results. A study conducted by Annuar et al. (2014) examined government ownership, family, and foreign ownership had a significant effect on tax avoidance. Research by Ying et al. (2017) which investigates government ownership and control versus institutional ownership, has a significant effect on tax avoidance. A study by Cabello et al. (2019) shows that managerial ownership has a significant effect on tax avoidance. On the other hand, research by Rusydi \& Martani (2014) shows that government and foreign ownership have no effect on tax avoidance. A study conducted by Fiandri \& Muid (2017) shows institutional ownership has no effect on tax avoidance. Research conducted by Charisma \& Dwimulyani (2019) shows that family ownership has no effect on tax avoidance. Another study (Santoso, 2014) shows public ownership has no effect on tax avoidance.

Based on the above problems, this study aims to test empirically the effect of ownership structure on tax avoidance. The contribution made contributes to the theory, especially Agency Theory which is the basis for corporate tax avoidance, contributes to the development of knowledge related to tax avoidance practices in Indonesia and the current implementation of corporate governance and provides a picture that the government as the regulator of policymaking can anticipate taxpayer behavior that might affect against state revenue from the tax sector.

\section{Literature review}

Agency theory is a contract given by the Principal to delegate authority to others (agents) in terms of corporate strategic decisions (Jensen \& Meckling, 1976). Agency theory is a contract to motivate the agent to act on behalf of the owner when the agent's interests are not following the owner's interests (Scott, 2003). Separation of ownership by the Principal with control by the Agent in a company tends to cause agency problems between the two. The principal as the owner of the capital wants to increase the value of the company's shares from the return on his investment, while

Rakayana, W., Sudarma, M., \& Rosidi, R. (2021). The structure of company ownership and tax avoidance in Indonesia. International Research Journal of Management, IT and Social Sciences, 8(3), 296-305. 
the management who is given a delegation by the principal to manage the company wants high compensation. The difference in the objectives of obtaining welfare is what causes management to adopt policies that are not in line with the interests of shareholders. The desire to maximize the welfare of each of them sometimes raises agency problems due to policymaking that is not in accordance with the objectives.

Agency theory argues that individuals are fully rational and have clear preferences and always want to fulfill their own desires to achieve wealth (Verbeeten, 2008). Agency theory assumes the existence of information asymmetry between management and shareholders. This allows managers to take opportunistic actions for personal gain. Principals need to provide appropriate incentives to motivate managers to improve work quality in running company operations in general and also to reduce opportunistic traits that may arise. This incentive is called agency cost.

One of the causes of agency problems is the company's capital structure. Ownership structure in the company has an important role in agency problems. Insider ownership and outsider ownership have the potential to cause anguish problems and also have the potential to reduce agency problems in the company. Conflicts of interest in agency problems might naturally occur in the company's ownership structure which is divided into 2, namely the ownership structure that is spread to public shareholders and the ownership structure with control over a handful of shareholders (La Porta et al., 1999).

The agency conflict type 1 occurs because the ownership structure of the company is scattered (La Porta et al., 1999). The scattered ownership structure generally occurs in common law countries with strong shareholder protection, such as in the United States, Britain, and Japan. Distributed share ownership is owned by many people in a small presentation. Thus, the control right of the company rests with the manager, not the shareholder. An agency conflict type 1 creates a conflict between the principal (shareholder) and the agent (management). Management makes policies that are personally beneficial and ignores the interests of shareholders with a conflict of interest.

The agency conflict type 2 occurs in companies with a concentrated ownership structure. Ownership structures are concentrated in countries that adhere to civil law, countries with weak legal protection for their investors. Conflicts that occur between majority shareholders and minority shareholders. A conflict occurs when the majority shareholder has the right to control the company and ignores the interests of the minority shareholder. Claessens et al. (2000) state that the ownership structure of companies in nine Asian countries shows that public companies in Asia have a concentrated interest structure.

\section{Family ownership structure on tax avoidance}

Agency conflicts in family firms have an impact on the costs and benefits of corporate tax avoidance. The role of the family owner influences the determination of company policy that determines company policy. Family companies owned by controlling shareholders tend to take personal advantage at the expense of minority shareholders (Shleifer \& Vishny, 1986). Family companies use tax avoidance practices to increase firm value and company profits and mislead minority investors (Desai \& Dharmapala, 2006). Cash flow deviations and control rights in family firms can reduce firm value.

The cost arising from tax avoidance are smaller than the benefits for the family company (Desai \& Dharmapala, 2006). Most family companies are managed by a family member, in particular, in countries where investor interests are weakly protected (Gaaya et al., 2017). The family firm is likely to profit from corporate control. Furthermore, controlling share ownership may worsen the interests of minority shareholders with voting rights in decision-making (La Porta et al., 1999). The hypothesis of this study is that family ownership has a positive effect on tax avoidance.

\section{Government ownership structure on tax avoidance}

Government ownership is unique in agency conflicts. It is explained that companies with government ownership are guaranteed political connections and are not monitored for company capital. This causes companies controlled by the government to have less supervision. Information asymmetry causes minority shareholders to not get detailed information. In non-Western developing countries such as in East Asia where the economic system is a market-based relationship, business, and politics are closely related. In a relationship-based system, companies can enjoy privileges such as favorable policies and government subsidies based on their political connections (Zeng, 2010).

Government ownership has a significant influence on managerial decisions through shareholders and political power (Liu \& Lu, 2007). Government ownership tends to maximize company resources with government monitoring to determine corporate tax planning with the aim of taking advantage and political connections (Wang et al., 2008). According to Faccio (2016), companies with political connections are positively related to tax aggressiveness. The low 
risk of tax audits makes companies more aggressive in tax planning, resulting in decreased transparency (Yu \& Yu, 2011). Weak witness enforcement of government companies makes tax evasion more aggressive (La Porta et al., 1999). The hypothesis of this study is that government ownership has a positive effect on tax avoidance.

\section{Institutional ownership structure on tax avoidance}

The majority shareholder of an institutional company often sacrifices the interests of other shareholders. On the other hand, for management, high profits have an effect on the amount of taxes that must be paid by the company and have an effect on company performance (Fiandri \& Muid, 2017). Based on the principal agency theory, the shareholders want to increase the performance and value of the company by promising compensation to the manager in return. In an effort to increase the value and performance of the company, there are factors that influence, one of which is the tax burden.

The high tax rates charged to companies make managers look for ways to reduce the taxes paid. The demand for an increase in shareholder value makes managers make strategies to minimize expenses and maximize profits (Arsyad \& Sodiq, 2014). The information presented in the financial statements by managers does not indicate the condition of the company due to information asymmetry. Tax avoidance is carried out by managers to meet the interests of shareholders and the interests of the manager. Little or the amount of institutional ownership in companies has an impact on corporate tax policy (Khurana \& Moser, 2013). The hypothesis of this study is that institutional ownership has a positive effect on tax avoidance.

\section{Foreign ownership structure on tax avoidance}

Foreign share ownership is related to the efficiency and profitability of the company (Annuar et al., 2014). The proportion of foreign ownership of shares in a company can affect the determination of company policy, the greater the share of foreign ownership, the greater the fairness of foreign investors in determining company policy in tax planning. Foreign investors who invest in companies in a country want an appropriate return on profits.

Foreign ownership and tax avoidance are only practiced in developing countries (Demirgüç-Kunt \& Huizinga, 2001). That study found that banks owned by foreign investors paid lower taxes in eighty countries. The higher the level of share ownership by foreign investors in a company is also directly proportional to the level of corporate tax avoidance (Salihu et al., 2015). The hypothesis of this study is that foreign ownership has a positive effect on tax avoidance.

\section{Managerial ownership structure on tax avoidance}

Share ownership by managers describes a manager's goal as principal and agent. Based on agency theory, stock owners are oriented towards high returns and company managers try to get compensation for their performance (Jensen \& Meckling, 1976a). When managers do not own company stock or only own a small number of shares in the company, the manager's actions are likely to be influenced by self-interest, not to increase the value of the company and the interests of the shareholders. Conversely, if managers own a part in the company or have a large number of shares, they tend to align their interests with the interests of shareholders in increasing bonuses and dividends (Alzoubi, 2016).

High managerial share ownership can increase the risk for companies involved in tax evasion (Cabello et al., 2019). High managerial ownership in a company can encourage them to take decisions to make risky investments such as tax avoidance to increase profits (Rego \& Wilson, 2011). The hypothesis of this study that managerial ownership has a positive effect on tax avoidance.

\section{Public ownership structure on tax avoidance}

Public ownership is a minority shareholding that owns shares of no more than 5\% of the total outstanding shares. Public shareholders are shareholders with minority power in the company. Companies that are concentrated on ownership and control are less aggressive in implementing tax avoidance practices than companies that have separate ownership and control (Badertscher et al., 2013; Zhou, 2001). Separation of ownership in large companies in decisionmaking can cause agency problems.

Small public ownership of shares does not have a big influence on the company in making decisions. This has an impact on determining company policy in the hands of managers who tend to be opportunistic in risky investments.

Rakayana, W., Sudarma, M., \& Rosidi, R. (2021). The structure of company ownership and tax avoidance in Indonesia. International Research Journal of Management, IT and Social Sciences, 8(3), 296-305. 
The existence of a role by the community as an obstacle to company earnings management has an impact on reducing company revenues. Earning management that is often done is that which increases income, in order to meet the expectations of the capital market and increase share prices (Santoso, 2014; Zahra et al., 2000). Investors who come from the public tend to look for companies with good profitability and have good corporate values. The hypothesis of this study is that public ownership has a positive effect on tax avoidance.

\section{Empirical Method}

\section{Sample data}

This study using companies listed on the Indonesia Stock Exchange (IDX). Taking companies that are listed on the Indonesia stock exchange (IDX). Sampling in the study using purposive sampling. Companies listed on the mainboard index during the 2017-2019 period. The company presents its Financial Reports and Annual Report from 2017-2019. The company did not have negative profits during 2017-2019. Cash Effective Tax Rates (CETR) is not more than one.

Table 1

Research Data Samples

\begin{tabular}{lc}
\hline \multicolumn{1}{c}{ Criteria } & Total Data \\
\hline BEI The company listed in main board index provided by BEI & 345 \\
\hline The company which does not have Financial report respectively during period of 2017-2019 & $(103)$ \\
\hline The company which has negative profit during $2017-2019$. & $(112)$ \\
\hline The company which has Cash Effective Tax Rates (CETR) more than one. & $(37)$ \\
\hline Number of company which fulfills the criteria in taking the sample & 93 \\
\hline
\end{tabular}

\section{Data analysis method}

This study used an equation model to test six research hypotheses. The method used in this study was panel data regression analysis for examiners and to analyze the effect of independent variables on the dependent variable with the addition of several control variables. In this study, the first model was used to see the effect of direct ownership structure on tax avoidance. The second equation model was created to test the ownership structure with the influence of control variables. The form of the regression model used in this study was as follows:

$$
\begin{gathered}
C T A_{i . t}=\alpha_{i}+\beta_{1} \text { Family }_{i . t}+\beta_{2} \text { Government }_{i . t}+\beta_{3} \text { Institutional }_{i . t}+\beta_{4} \text { Foreign }_{i . t}+ \\
\beta_{5} \text { Managerial }_{i . t}+\beta_{6} \text { Public }_{i . t}+\epsilon_{i . t}
\end{gathered}
$$

Letter $\mathrm{i}$ and $\mathrm{t}$ indicate company and year, respectively. CTA is corporate tax evasion measured as tax cash paid divided by profit before tax. $\boldsymbol{\alpha}_{\boldsymbol{i}}$ is a constant; $\beta_{1}$ to $\beta_{6}$ are regression coefficients; $\dot{\epsilon}$ is an error of the model. The measurement of family ownership used the percentage of shares owned by the family divided by the shares outstanding (Gaaya et al., 2017). The measurement of government uses the percentage of shares owned by the government divided by outstanding shares (Zeng, 2010). Institutional ownership is measured as the percentage of shares owned by institutions of the company's total share ownership (Ying et al., 2017; Lewellen et al., 1985). Foreign ownership is measured as the percentage of shares owned by foreigners to the company's total share ownership (Salihu et al., 2015) Managerial share ownership is measured using the percentage of shares of the company is measured using the percentage of shares 
of company managers, commissioners, and directors (Pramudito \& Ratna Sari, 2015). Public share ownership is measured using the percentage of public ownership in the company (Resti Yulistia et al., 2020).

$$
\begin{array}{r}
\text { CTA }_{i . t}=\alpha_{i}+\beta_{1} \text { Family }_{i . t}+\beta_{2} \text { Government }_{i . t}+\beta_{3} \text { Institutional }_{i . t}+\beta_{4} \text { Foreign }_{i . t} \\
\beta_{5} \text { Managerial }_{i . t}+\beta_{6} \text { Public }_{i . t}+\beta_{7} \text { Profit }_{i . t}+\beta_{8} \text { Lev }_{i . t}+\beta_{9} \text { size }_{i . t}+\epsilon_{i . t}
\end{array}
$$

The second equation model was created to test the ownership structure with the influence of control variables. Firm size, profitability, leverage, and capital intensity are controlled variables that are found no affect the company's tax burden. These are denoted as size, profit, lev, respectively. The size was measured as the natural logarithm of the company's total assets. Profit is measured as net profit after tax by total assets, lev as total debt to total assets.

\section{Results}

Table 2

Descriptive Analysis

\begin{tabular}{l|c|c|c|c|c}
\hline \multicolumn{1}{c|}{ Variable } & $\mathrm{N}$ & Minimum & Maximum & Mean & Std. Dev \\
\hline ETR & 279 & 0,00 & 0.52 & 0,25 & 0.12 \\
\hline Family & 279 & 0,01 & 0.93 & 0,40 & 0.11 \\
\hline Government & 279 & 0,51 & 0.80 & 0,65 & 0,03 \\
\hline Institutional & 279 & 0,01 & 0,93 & 0.57 & 0.12 \\
\hline Foreign & 279 & 0,16 & 0,94 & 0.56 & 0.09 \\
\hline Managerial & 279 & 0,30 & 0,55 & 0.33 & 0.01 \\
\hline Public & 279 & 0,10 & 0,83 & 0.38 & 0.09 \\
\hline ROA & 279 & 0,00 & 0,77 & 0.07 & 0,07 \\
\hline Leverage & 279 & 0,01 & 1,05 & 0.29 & 0,28 \\
\hline Size & 279 & 25,69 & 34,89 & 29,84 & 1,84
\end{tabular}

The results of descriptive statistics in the study are presented in the table above. The ETR variable has an average value of 0.25 and a standard deviation value of 0.12 .

The family ownership variable has a mean value of 0.35 and a standard deviation of 0.22 . the government variable has a mean value of 0.51 and a standard deviation of 0.23 . the institutional ownership variable has a mean value of 0.40 and a standard deviation of 0.25 . the foreign ownership variable has a mean value of 0.36 , with a standard deviation of 0.30 . the managerial ownership variable has a mean value of 0.33 with a standard deviation of 0.01 . the public variable has a mean value of 0.38 with a standard deviation of 0.09 .

The control variable ROA has a mean value of 0.07 , a maximum and minimum value of 0.77 , and 0.00 with a standard deviation of 0.07 . Thus, the value of the leverage control variable has a mean of 0.29 with a min and max value of 0.01 and 1.05 and a standard deviation of 0.28 . The control variable company size has a mean value of 29.84 , min and max values of 25.69 and 34.89 with a standard deviation of 1.84 . it can be concluded that the sample above has low variability. This can be seen from the magnitude of the standard deviation which is below the average sample value above.

Table 3

Results of Regression Analysis Model 1

\begin{tabular}{ccccc}
\hline Variable & Coef & $T$ & P-Value & R-squared \\
\hline Family & 0,00 & 0,139 & 0,88 & \\
Government & 0,87 & 3,422 & 0,00 & \\
Institutional & 0,00 & 0,142 & 0,88 & 0,06 \\
Foreign & 0,21 & 2,684 & 0,00 & \\
Managerial & $-0,06$ & $-0,140$ & 0,88 & \\
\hline
\end{tabular}

Rakayana, W., Sudarma, M., \& Rosidi, R. (2021). The structure of company ownership and tax avoidance in Indonesia. International Research Journal of Management, IT and Social Sciences, 8(3), 296-305. 


\begin{tabular}{cccc}
\hline Public & 0,05 & 0,695 & 0,48 \\
Con & $-0,44$ & $-1,84$ & 0,06 \\
\hline
\end{tabular}

The coefficient obtained by the family variable has a value of 0.00 with a significance of 0.88 ( $p>0.05)$. This indicates that there is no influence between family variables and tax avoidance. The institutional variable coefficient value has a value of 0.00 with a significant value of 0.88 ( $p>0.05$ ). Therefore, there is no influence between institutional variable and tax avoidance variable. Managerial and public coefficients have values of -0.06 and 0.05 with a significance of $0.08(p>0.05)$ and $0.48(p>0.05)$. This shows that there is no influence for the managerial variable and public variable. The coefficient of determination obtained in model 1 is 0.06 . Therefore, the influence of the independent variable on the dependent variable is 6 percent.

Based on Table 3, it can be concluded that family ownership is not in accordance with the study conducted by Shleifer \& Vishny (1986) that the companies owned by family controlling shareholders tend to take personal advantage at the expense of minority shareholders. The regression results of institutional ownership are different from the results of the analysis in research conducted by Khan et al. (2017) which prove that institutional ownership encourages more aggressive tax planning, increases profit margins, and gets direct benefits from tax avoidance.

Managerial ownership has no effect on corporate tax avoidance because managerial share ownership in Indonesian companies is very small, which is below 5\%. Low ownership results in very fewer control rights of managers in making policies at top-level management compared to other shareholders (Junilla \& Yenni, 2014; Lefort \& Urzúa, 2008). Furthermore, public ownership has no effect on tax avoidance, which is because public shareholders cannot have an impact and do not the existence of control over corporate tax avoidance behavior (Santoso, 2014).

Table 4

Results of Regression Analysis Model 2

\begin{tabular}{ccccc}
\hline Variable & Coef & $T$ & $P$-Value & R-squared \\
\hline Family & 0,03 & 0,60 & 0,54 & \\
Government & 0,97 & 3,78 & 0,00 & \\
Institutional & 0,01 & 0,29 & 0,77 & \\
Foreign & 0,22 & 2,80 & 0,05 & \\
Managerial & $-0,01$ & $-0,02$ & 0,97 & 0,09 \\
Public & 0,05 & 0,65 & 0,51 & \\
ROA & $-0,12$ & $-1,52$ & 0,12 & \\
Leverage & $-0,04$ & $-1,40$ & 0,16 & \\
Size & 0,01 & 2,18 & 0,02 & \\
Con & $-0,84$ & $-2,79$ & 0,00 & \\
\hline
\end{tabular}

In model 2 , the constant value is -0.84 . This indicates that there is no correlation between the independent variable and the control variable. The government has a coefficient of 0.97 with a significance value of $0.00(p<0.05)$, which means that there is an influence between government variables and tax avoidance variables. Furthermore, the foreign variable has a coefficient value of 0.22 with a significance value of $0.05(\mathrm{p}<0.05)$ indicating that there is an influence between the foreign variable and tax avoidance variable.

The control variable ROA has a coefficient value of -0.12 and a significant value of 0.12 indicating that it does not affect the tax avoidance variable. The leverage variable has a coefficient value of -0.04 with a significance value of 0.16 indicating that the leverage control variable has no effect on the tax avoidance variable. The size variable has a coefficient value of 0.01 with a significance value of 0.02 . Therefore, it has an influence on the tax avoidance variable. The coefficient of determination obtained in model 2 is 0.09 . Thus, the influence of the independent variable on the dependent variable is 9 percent.

The results of regression analysis of model 1 and model 2 of government ownership variable have a significant positive effect on tax avoidance. The results of this study are supporting the results of a previous study conducted by Ying et al. (2017) which proves that government ownership has a positive effect on tax avoidance. Companies that have government ownership pay less tax since they take advantage of the benefits arising from political connections. The political connections owned by government companies encourage management to be more aggressive in carrying out tax planning through tax avoidance (Faccio, 2016; Kuvaas, 2003). The purpose of this management is to increase 
profits for the management itself and get a promotion. The existence of political connections owned by government companies creates agency problems between minority and majority shareholders because there is no transparency in tax planning made by companies owned by the government in making decisions.

The structure of foreign ownership in this study has a significant positive effect on tax avoidance as seen from the results of the regression analysis model 1 and model 2. The results of this study are supporting a previous study carried out by Annuar et al (2014), which proves that foreign ownership of listed companies in Malaysia has the potential for tax evasion. Share ownership owned in a company contributes to the determination of company policy. The results of this study are also supported by research from Salihu et al (2015) which states that foreign investors try to exploit the company's operations by avoiding taxes to get the highest possible profit. This causes foreign investors to put more pressure on managers to be as efficient as possible in using resources and can provide high profits, one of which is by manipulating the tax burden. Therefore, it has an impact on minority shareholders due to the asymmetry of information provided by management.

In this study, the size variable has a significant effect on tax avoidance in the regression model 2 . This shows that the greater the size of the company, the more aggressive the tac action of a company is. With the size of a large company, it tends to have large assets and resources to minimize the tax burden (Ricardson, 2007; Anderson, 1984). In this study, the ROA variable did not have a significant effect on tax avoidance. Companies that tend to avoid taxes have a high level of profitability because they have the ability to plan taxes to avoid taxes (Rusydi \& Martani, 2014). In this study, the leverage variable has no effect on tax avoidance. This is due to the supervision and regulation regarding the amount of debt ratio that can be used for company operations in tax Law Number 36 of 2008 . The existence of these restrictions affects the company's finances because the higher the amount of third-party funding used by the company. The higher the interest costs arising from profits can encourage the company to seek tax avoidance.

\section{Conclusion}

This study aims to examine the effect of corporate ownership structure on the avoidance of liability in Indonesia. Based on the analysis and discussion of the research results, the agency problem between majority and minority shareholders in government companies is due to the absence of information transparency which causes information asymmetry. Ownership of government shares due to political connections to the government as the owner of the company, government companies have the privilege to reduce the company's tax burden. Managers in government companies have strong political connections with the government to be able to ease the corporate tax burden.

High foreign ownership in a company can affect company policy. This causes foreign investors to put more pressure on managers to be able to provide high profits by manipulating the tax burden. Foreign investors tend to invest their funds in developing countries such as Indonesia. This is due to weak regulations on the protection of minority shareholders. Therefore, foreign investors can divert profits to companies from the country of origin.

The size of the company has a role in strengthening the influence of the ownership structure in carrying out tax actions. The larger the size of the company with good resources and management can encourage companies to plan taxes in order to avoid high tax burdens.

It is suggested that future research can be related to the measurement of tax avoidance and share ownership variable that is compared to other measurements to obtain good data. Furthermore, the amount of data used is expected to be bigger to avoid invalid data.

\section{Conflict of interest statement}

The author(s) declared that they have no competing interests.

\section{Statement of authorship}

The author(s) have a responsibility for the conception and design of the study. The author(s) have approved the final article.

\section{Acknowledgments}

We are grateful to two anonymous reviewers for their valuable comments on the earlier version of this paper.

Rakayana, W., Sudarma, M., \& Rosidi, R. (2021). The structure of company ownership and tax avoidance in Indonesia. International Research Journal of Management, IT and Social Sciences, 8(3), 296-305. 


\section{References}

Alzoubi, E. S. S. (2016). Ownership structure and earnings management: Evidence from Jordan. International Journal of Accounting and Information Management. https://doi.org/10.1108/JJAIM-06-2015-0031

Amri, M. (2017). The Effect of Management Compensation Towards Tax Avoidance With Moderation of Direction Gender Diversification and Preference of Company Executive Risk in Indonesia. ASET (Research Accounting) Journal. https://doi.org/10.17509/jaset.v9i1.5253

Anderson, E. E. (1984). The growth and performance of franchise systems: company versus franchisee ownership. Journal of Economics and Business, 36(4), 421-431. https://doi.org/10.1016/0148-6195(84)90024-9

Annuar, H. A., Salihu, I. A., \& Obid, S. N. S. (2014). Corporate Ownership, Governance and Tax Avoidance: An Interactive Effects. Procedia - Social and Behavioral Sciences. https://doi.org/10.1016/j.sbspro.2014.11.063

Arsyad, L., \& Sodiq, A. (2014). The Effect of Corporate Governance, Company Size, Fiscal Loss Compensation, and Ownership Structure Towards Tax Avoidance. Lincolin Arsyad.

Badertscher, B. A., Katz, S. P., \& Rego, S. O. (2013). The separation of ownership and control and corporate tax avoidance. Journal of Accounting and Economics. https://doi.org/10.1016/j.jacceco.2013.08.005

Cabello, O. G., Gaio, L. E., \& Watrin, C. (2019). Tax avoidance in management-owned firms: evidence from Brazil. International Journal of Managerial Finance. https://doi.org/10.1108/IJMF-04-2018-0117

Charisma, R. B., \& Dwimulyani, S. (2019). The Influence of Ownership Structure Towards Tax Avoidance Action With Audit Quality As Moderating Variable. Proceeding of Expert National Seminar.

Claessens, S., Djankov, S., \& Lang, L. H. P. (2000). The separation of ownership and control in East Asian Corporations. Journal of Financial Economics. https://doi.org/10.1016/s0304-405x(00)00067-2

Demirgüç-Kunt, A., \& Huizinga, H. (2001). The taxation of domestic and foreign banking. Journal of Public Economics. https://doi.org/10.1016/S0047-2727(00)00071-2

Desai, M. A., \& Dharmapala, D. (2006). Corporate tax avoidance and high-powered incentives. Journal of Financial Economics. https://doi.org/10.1016/j.jfineco.2005.02.002

Faccio, M. (2016a). Discussion of "Corporate Political Connections and Tax Aggressiveness." Contemporary Accounting Research. https://doi.org/10.1111/1911-3846.12214

Faccio, M. (2016b). Kim, C. F., \& Zhang, L. (2015). Corporate political connections and tax aggressiveness. Contemporary Accounting Research. Contemporary Accounting Research.

Fiandri, K. A., \& Muid, D. (2017). The Effect of Institutional Ownership And Company Size Towards Tax Avoidance. Diponegoro Journal of Accounting.

Gaaya, S., Lakhal, N., \& Lakhal, F. (2017). Does family ownership reduce corporate tax avoidance? The moderating effect of audit quality. Managerial Auditing Journal. https://doi.org/10.1108/MAJ-02-2017-1530

Jensen, M. C., \& Meckling, W. H. (1976a). Theory of the Firm: Managerial. Journal of Financial Economics. https://doi.org/http://dx.doi.org/10.1016/0304-405X(76)90026-X

Jensen, M. C., \& Meckling, W. H. (1976b). Theory of the firm: Managerial behavior, agency costs and ownership structure. Journal of Financial Economics. https://doi.org/10.1016/0304-405X(76)90026-X

Junilla, H., \& Yenni, M. (2014). Pengaruh Struktur Kepemilikan dan Karakteristik Dewan Terhadap Agresivitas Pajak The Effect of Ownership Structure and Board Characteristics Towards Tax Aggressiveness. TAX \& ACCOUNTING REVIEW.

Ministry of Finance (2019) Information Book of APBN 2019 https://www.kemenkeu.go.id/

Kuvaas, B. (2003). Employee ownership and affective organizational commitment: employees' perceptions of fairness and their preference for company shares over cash. Scandinavian Journal of Management, 19(2), 193-212. https://doi.org/10.1016/S0956-5221(01)00044-6

Khan, M., Srinivasan, S., \& Tan, L. (2017). Institutional ownership and corporate tax avoidance: New evidence. Accounting Review. https://doi.org/10.2308/accr-51529

Khurana, I. K., \& Moser, W. J. (2013). Institutional shareholders' investment horizons and tax avoidance. Journal of the American Taxation Association. https://doi.org/10.2308/atax-50315

Lefort, F., \& Urzúa, F. (2008). Board independence, firm performance and ownership concentration: Evidence from Chile. Journal of Business Research, 61(6), 615-622. https://doi.org/10.1016/j.jbusres.2007.06.036

La Porta, R., Lopez-de-Silanes, F., \& Shleifer, A. (1999). Corporate ownership around the world. Journal of Finance. https://doi.org/10.1111/0022-1082.00115

Lewellen, W., Loderer, C., \& Rosenfeld, A. (1985). Merger decisions and executive stock ownership in acquiring firms. Journal of Accounting and Economics, 7(1-3), 209-231. https://doi.org/10.1016/0165-4101(85)90038-2

Liu, Q., \& Lu, Z. (Joe). (2007). Corporate governance and earnings management in the Chinese listed companies: A 
tunneling perspective. Journal of Corporate Finance. https://doi.org/10.1016/j.jcorpfin.2007.07.003

Pramudito, B., \& Ratna Sari, M. (2015). The Effect of Accounting Conservatism, Managerial Ownership, and Size of Commissioner Board Towards Tax Avidance. E-Journal Accounting.

Rego, S. O., \& Wilson, R. (2011). Executive Compensation, Tax Reporting Aggressiveness, and Future Firm Performance. In Working Paper, University of Lowa.

Resti Yulistia, M., Minovia, A. F., Andison, \& Fauziati, P. (2020). Ownership structure, political connection and tax avoidance. International Journal of Innovation, Creativity and Change.

Richardson, Grant \& Roman Lanis. (2007). Determinants of the variability in corporate effective tax rates and tax reform: Evidence from Australia. Journal Of Accounting And Public Policy

Rusydi, M. K., \& Martani, D. (2014). The Effect of Ownership Structure Towards Aggressive Tax Avoidance. National Symposium of Accounting XVII.

Santoso, Titus Bayu, \& Dul Muid. (2014). The Effect of Corporate Governance Towards Company Tax Avoidance. Diponegoro Journal Of Accounting

Salihu, I. A., Annuar, H. A., \& Sheikh Obid, S. N. (2015). Foreign investors' interests and corporate tax avoidance: Evidence from an emerging economy. Journal of Contemporary Accounting and Economics. https://doi.org/10.1016/j.jcae.2015.03.001

Shane, S. (2003). A general theory of entrepreneurship: The individual-opportunity nexus. In A General Theory Of Entrepreneurship: The Individual-Opportunity Nexus. https://doi.org/10.4337/9781781007990

Shleifer, A., \& Vishny, R. W. (1986). Large Shareholders and Corporate Control. Journal of Political Economy. https://doi.org/10.1086/261385

Suandy, E. (2011). Perencanaan Pajak. In Perencanaan Pajak (Edisi 5).

Constitution. (2009). The Constitution of Republic of Indonesia Number 16 Year of 2009 About Fourth Change of The Constitution Number Year of 1983 About General Provision and Procedure To Be The Consitution. Constitution Number 16 Year of 2009.

Constitution of Republic of Indonesia Number 36 Year of 2008 about Income Tax

Verbeeten, F. H. M. (2008). Performance management practices in public sector organizations: Impact on performance. Accounting, Auditing and Accountability Journal. https://doi.org/10.1108/09513570810863996

Wang, Q., Wong, T. J., \& Xia, L. (2008). State ownership, the institutional environment, and auditor choice: Evidence from China. Journal of Accounting and Economics. https://doi.org/10.1016/j.jacceco.2008.04.001

Ying, T., Wright, B., \& Huang, W. (2017). Ownership structure and tax aggressiveness of Chinese listed companies. International Journal of Accounting and Information Management. https://doi.org/10.1108/IJAIM-07-2016-0070

Yu, F., \& Yu, X. (2011). Corporate Lobbying and Fraud Detection. The Journal of Financial and Quantitative Analysis, 46(6), 1865-1891

Zahra, S. A., Neubaum, D. O., \& Huse, M. (2000). Entrepreneurship in medium-size companies: Exploring the effects of ownership and governance systems. Journal of management, 26(5), 947-976. https://doi.org/10.1016/S01492063(00)00064-7

Zhou, X. (2001). Understanding the determinants of managerial ownership and the link between ownership and performance: comment. Journal of financial economics, 62(3), 559-571. https://doi.org/10.1016/S0304$405 \mathrm{X}(01) 00085-\mathrm{X}$

Zeng, T. (2010). Ownership Concentration, State Ownership, and Effective Tax Rates: Evidence from China's Listed Firms*. Accounting Perspectives. https://doi.org/10.1111/j.1911-3838.2010.00014.x

Rakayana, W., Sudarma, M., \& Rosidi, R. (2021). The structure of company ownership and tax avoidance in Indonesia. International Research Journal of Management, IT and Social Sciences, 8(3), 296-305. 